\title{
WESTWARD EXPANSION OF THE EVENING BAT (NYCTICEIUS HUMERALIS) IN THE UNITED STATES, WITH NOTES ON THE FIRST RECORD FROM NEW MEXICO
}

\author{
Brett R. Andersen ${ }^{1,4}$, Keith Geluso ${ }^{1}$, Hans W. Otto ${ }^{2}$, and Larisa Bishop-Boros ${ }^{3}$
}

\begin{abstract}
The general lack of trees in the Great Plains has limited colonization by eastern woodland mammals in the past, but recent expansion of forests in corridors along prairie waterways and in towns has enabled an assortment of woodland species to expand distributional ranges westward. The evening bat (Nycticeius humeralis) historically occurred in woodlands throughout the eastern United States. Following our capture of the first evening bat in New Mexico, we updated the distributional range for this species by amassing recent records from published literature and museum voucher records west of its historic range published in 1981, the last time the species distribution was updated throughout its range. We document that evening bats, including some reproductively active populations, now occur across much of the central and southern Great Plains, including southwestern Nebraska, western Kansas, and western Texas. Such records should encourage researchers to factor in the possible occurrence of this species beyond published historic western limits for mist-netting and acoustic surveys. While it remains unclear if the single capture in southwestern New Mexico represented a wandering individual, these compiled records suggest that established populations might occur west of our updated distribution for the species.
\end{abstract}

Resumen._La falta de árboles en general en las Grandes Llanuras ha limitado la colonización de los mamíferos del bosque del este, pero la reciente expansión de los bosques en los corredores que se encuentran a lo largo de las vías fluviales de las praderas y en las ciudades, ha permitido que una variedad de especies de bosque extienda su rango de distribución hacia el oeste. Históricamente, podíamos encontrar al murciélago crepuscular americano (Nycticeius humeralis) en los bosques del este de los Estados Unidos. Luego de la captura de nuestro primer murciélago crepuscular americano ( $N$. humeralis) en Nuevo México, actualizamos el rango de distribución de esta especie, recopilando registros de publicaciones recientes y anteriores, al oeste de su rango histórico publicado en 1981, fecha en la que se actualizó por última vez el rango de distribución de esta especie. Reportamos que podemos encontrar al murciélago crepuscular americano, incluyendo a algunas poblaciones reproductivamente activas, en gran parte de la zona central y sur de las Grandes Llanuras, incluyendo el suroeste de Nebraska, el oeste de Kansas y el oeste de Texas. Tales registros deberían alentar a los investigadores a tener en cuenta la posible existencia de esta especie más allá de los límites históricos occidentales publicados, a la hora de realizar estudios acústicos y al colocar redes de captura. Aunque aún no está claro si la captura realizada en el suroeste de Nuevo México representa a un ejemplar errante, los registros recopilados sugieren que podríamos encontrar poblaciones de esta especie al oeste de nuestra distribución ya actualizada.

Numerous mammals inhabiting eastern forests have expanded their distributional ranges westward in response to recent phytogeographic changes throughout the Great Plains (Choate and Reed 1986, Benedict et al. 1996, 2000, Wilson and Choate 1996, Geluso 2004, 2006, Yancey and Jones 2006). This sparsely forested region, from central Canada through 9 Midwestern states into northern Mexico (Mather 1972), once served as a western barrier to eastern woodland species. However, anthropogenic influences, including dams, fire suppression, and European settlement in prairies, have led to widespread increases in woodlands along riparian corridors and in towns (Hunt 1965, Johnson 1994, Benedict et al. 1996). Because of their capability for powered flight, bats are able to rapidly respond to the presence of expanding and shifting habitats (Scheel et al. 1996, Kurta et al. 2007). Tree-roosting species, including the American Perimyotis (Perimyotis subflavus, formerly Pipistrellus subflavus), eastern red bat (Lasiurus borealis), and Seminole bat (Lasiurus seminolus), appear to have exploited forested habitats in parts of the Great Plains, as records of these eastern species now occur outside of their historic ranges (Hall 1981, Benedict et al. 2000, Brant and Dowler 2000, Geluso et al. 2005, White et al. 2006, Armstrong

${ }^{1}$ Biology Department, University of Nebraska at Kearney, Kearney, NE 68845

${ }^{2}$ Department of Ecology and Evolutionary Biology, University of Arizona, Tucson, AZ 85721.

${ }^{3}$ Western Ecosystems Technology, Inc., Laramie, WY 82070

4E-mail: andersenbr@lopers.unk.edu 


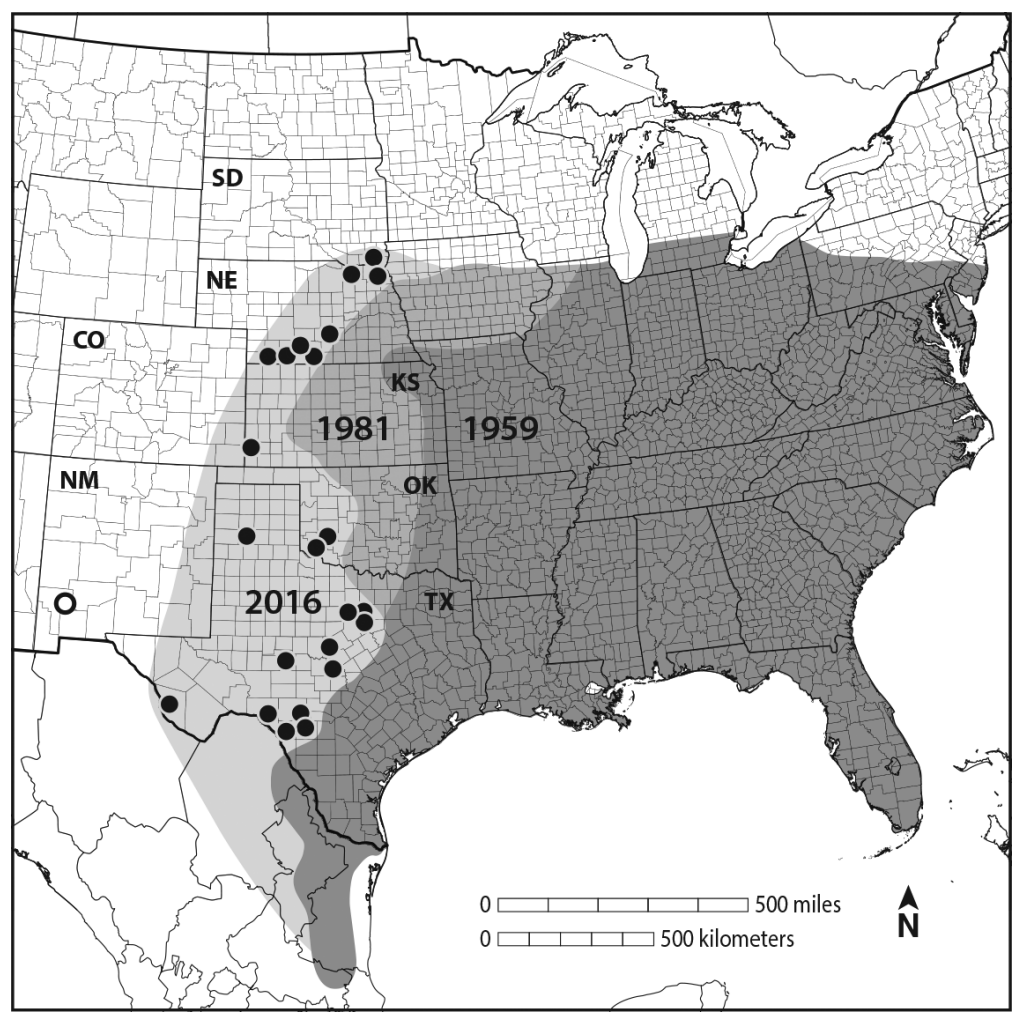

Fig. 1. Distributional map of the evening bat (Nycticeius humeralis) representing the historical ranges developed by Hall and Kelson (1959) and Hall (1981), as well as the updated range including all county records identified since Hall (1981; black dots). The open circle in New Mexico represents the first record of $N$. humeralis in the state, but due to its location, it was not included in the proposed distribution and needs to be considered an extralimital record until more specimens are captured in New Mexico.

et al. 2006, Valdez et al. 2009, Riedle and Matlack 2013, Geluso and Geluso 2016).

The evening bat (Nycticeius humeralis) inhabits temperate woodlands across most of the eastern and southeastern United States (Hall 1981, Watkins and Shump 1981). Prior to 1981, N. humeralis was known to occur from New Jersey westward to southern Michigan and southeastern Nebraska, and southward, inhabiting central Kansas, Oklahoma, and Texas to northeastern Mexico (Hall 1981, Watkins and Shump 1981). Because the species commonly roosts in trees and buildings (Watkins 1972, Boyles and Robbins 2006), the historical lack of trees across the Great Plains likely restricted its colonization of the region in the past (Altringham 2011).

In this study, we amassed distributional records through 2017 across the Great Plains to update the western distributional limits of $N$. humeralis. Several publications have updated the distribution of this species at the state level (i.e., Sparks and Choate 2000-Kansas; Benedict 2004-Nebraska; Ammerman et al. 2012-Texas), but a comprehensive assessment of the species throughout its distribution has not been completed since Hall (1981). Furthermore, we report on the first capture of $N$. humeralis in New Mexico. We discuss potential routes for this capture in southwestern New Mexico and implications associated with westward expansion of this species and other eastern bat species across the Great Plains.

\section{Methods}

\section{Literature Review}

We amassed museum records of $N$. humeralis through online databases, as well as direct communications with museums along the edge of the species' distribution in Texas, Oklahoma, and New Mexico. We examined 
TABLE 1. Records for evening bats (Nycticeius humeralis) outside of the previously published distributional limits in Hall (1981). Year represents the first year the species was documented in the county.

\begin{tabular}{|c|c|c|c|c|}
\hline State & County & Year & Museum ${ }^{\mathrm{a}}$ & Reference \\
\hline Kansas & Stanton & 2007 & FHSM & Phelps et al. 2008 \\
\hline Nebraska & Buffalo & 2013 & UNSM & Johnson and Geluso 2017 \\
\hline Nebraska & Dixon & 1988 & UNSM & Benedict et al. 2000 \\
\hline Nebraska & Furnas & 2004 & UNSM & Johnson and Geluso 2017 \\
\hline Nebraska & Harlan & 2006 & MSB & Geluso et al. 2008 \\
\hline Nebraska & Hitchcock & 2007 & UNSM & Serbousek and Geluso 2009 \\
\hline Nebraska & Knox & 2001 & UNSM & Benedict 2004 \\
\hline Nebraska & Red Willow & 2007 & UNSM & Serbousek and Geluso 2009 \\
\hline New Mexico & Grant & 2015 & MSB & This study \\
\hline Oklahoma & Jackson & 1978 & $\mathrm{UCO}$ & $\mathrm{N} / \mathrm{A}$ \\
\hline Oklahoma & Kiowa & 2007 & $\mathrm{OU}$ & $\mathrm{N} / \mathrm{A}$ \\
\hline South Dakota & Clay & 2000 & None ${ }^{b}$ & Lane et al. 2003 \\
\hline Texas & Brown & 2002 & ASNHC & Ammerman et al. 2012 \\
\hline Texas & Hood & 2009 & TTU & Demere et al. 2012 \\
\hline Texas & Kinney & 1986 & TTU & Manning et al. 1987 \\
\hline Texas & Palo Pinto & 1971 & MWSU & $\mathrm{N} / \mathrm{A}$ \\
\hline Texas & Parker & 2005 & ASNHC & Ammerman et al. 2012 \\
\hline Texas & Presidio & 1996 & ASNHC & Dowler et al. 1999 \\
\hline Texas & Randall & 2006 & TTU & Riedle and Matlack 2013 \\
\hline Texas & Real & 1986 & TTU & Davis and Schmidly 1994 \\
\hline Texas & San Saba & 1976 & TCWC & Wilkins et al. 1979 \\
\hline Texas & Tom Green & 1992 & ASNHC & Dowler et al. 1992 \\
\hline Texas & Uvalde & 1972 & TCWC & Ammerman et al. 2012 \\
\hline Texas & Val Verde & 1998 & ASNHC & Dowler et al. 1999 \\
\hline
\end{tabular}

aAcronyms for museums: ASNHC = Angelo State Natural History Collection, San Angelo, TX; FHSM = Fort Hays State Museum, Hays, KS; MSB = Museum of Southwestern Biology, Albuquerque, NM; OU = Sam Noble Oklahoma Museum of Natural History, Norman, OK; TCWC = Texas Cooperative Wildlife Collection, College Station, TX; TTU = Museum of Texas Tech University, Lubbock, TX; UCO = University of Central Oklahoma Natural History Museum, Edmond, OK; UNSM = University of Nebraska State Museum, Lincoln, NE.

bNo voucher was kept according to Swier 2006.

online databases for records from 92 reporting museums via VertNet (vertnet.org) on 31 January 2017. In addition, we contacted curators and collection managers from Central Oklahoma University (COU), Midwestern State University (MWSU), and Eastern New Mexico University (ENMU), which were not linked with VertNet and did not possess accessible online databases. Distributional records only were included if the entire county was located outside of the historical distribution described in Hall (1981).

\section{Fieldwork}

The study site for our field research was located on the Mimbres River in Grant County, New Mexico, about $1.2 \mathrm{~km}$ north of Bear Canyon Reservoir $\left(32.89776^{\circ} \mathrm{N}, 107.99616^{\circ} \mathrm{W}\right.$; North American Datum 1983). Upland habitats surrounding the riparian area consisted of piñon-juniper woodlands. Dominant trees adjacent to this small endorheic river consisted of cottonwood (Populus spp.), box elder (Acer negundo), Goodding's willow (Salix gooddingii), Arizona black walnut (Juglans major), and alder (Alnus oblongifolia).
On 5 nights in 2014 and 2015 (8 and 9 June 2014, 18 and 29 May and 3 June 2015), we deployed mist nets (Avinet Inc., Portland, ME) in areas of calm water or river sections where tree canopy forced bats into tight corridors. A voucher specimen was deposited at the Museum of Southwestern Biology (MSB), University of New Mexico, Albuquerque, New Mexico. All fieldwork was conducted under an approved animal care and use protocol (\#020614) from the University of Nebraska at Kearney and met guidelines recommended by the American Society of Mammalogists (Sikes et al. 2011).

\section{RESUlTS}

\section{Literature Review}

Our review of the literature and museum records yielded a total of 23 county records west of the historical distributional range of N. humeralis described in Hall (1981) from the following states: South Dakota (1), Nebraska (7), Kansas (1), Oklahoma (2), and Texas (12) (Fig. 1, Table 1). These records included one state record (South Dakota; Lane et al. 2003) 
TABLE 2. Total bats captured along the Mimbres River in Grant County, New Mexico, in 2014 and 2015. We attempted to capture bats on 5 nights at a location approximately $4 \mathrm{~km} \mathrm{~N}$ of Mimbres along a $0.7-\mathrm{km}$ stretch of river.

\begin{tabular}{|c|c|c|c|c|c|}
\hline Scientific name & Common name & Male & Female & Unknown & Total \\
\hline Lasionycteris noctivagans ${ }^{\mathrm{a}}$ & Silver-haired bat & $35(2)$ & $1(1)$ & 0 & $36(3)$ \\
\hline Lasiurus cinereus ${ }^{\mathrm{a}}$ & Hoary bat & $15(2)$ & $16(13)$ & 2 & $33(15)$ \\
\hline Myotis occultus ${ }^{\mathrm{a}}$ & Southwestern myotis & $7(3)$ & $1(0)$ & 0 & $8(3)$ \\
\hline Myotis californicus ${ }^{\mathrm{a}}$ & California myotis & $1(0)$ & $6(2)$ & 0 & $7(2)$ \\
\hline Myotis thysanodes & Fringed myotis & $0(0)$ & $2(0)$ & 1 & $3(0)$ \\
\hline Eptesicus fuscus ${ }^{\mathrm{a}}$ & Big brown bat & $0(0)$ & $2(1)$ & 0 & $2(1)$ \\
\hline Tadarida brasiliensis & Brazilian free-tailed bat & $1(0)$ & $1(0)$ & 0 & $2(0)$ \\
\hline Lasiurus blossevillii & Western red bat & $1(0)$ & $0(0)$ & 0 & $1(0)$ \\
\hline Myotis volans & Long-legged myotis & $0(0)$ & $1(0)$ & 0 & $1(0)$ \\
\hline Myotis yumanensis & Yuma myotis & $1(1)$ & $0(0)$ & 0 & $1(1)$ \\
\hline Nycticeius humeralis ${ }^{\mathrm{a}}$ & Evening bat & $1(1)$ & $0(0)$ & 0 & $1(1)$ \\
\hline TOTAL & & $62(9)$ & $30(17)$ & 3 & $95(26)$ \\
\hline
\end{tabular}

andicates species captured on the night that the state record $N$. humeralis was captured. Totals for that night are in parentheses.

and one record in western Kansas which was located only $2 \mathrm{~km}$ east of Baca County, Colorado (Phelps et al. 2008). Following an extensive literature review and compilation of specimens by Ammerman et al. (2012), researchers were able to accumulate records of $N$. humeralis both inside and outside of the species' historical range in Texas. Three additional counties in Texas (Bailey, Midland, and Yoakum cos.) were stated to have records of $N$. humeralis west of its known historical range; however, we chose not to include these as they represented unverified records from the Texas Department of State Health Services (Ammerman et al. 2012). Only one new county record (Randall Co.; Riedle and Matlack 2013) has been identified in western parts of Texas since Ammerman et al. (2012). These records indicate that $N$. humeralis now occurs across a majority of the Great Plains states, including southwestern Nebraska, western Kansas, western Oklahoma, and western Texas.

\section{Field Work}

On 18 May 2015, we captured 26 bats representing 7 species in 3 nets deployed from 20:00 (MST) to midnight. Among those captures was a nonreproductive, adult male evening bat at 20:45 (MST), representing the first record for New Mexico (Table 2). The individual weighed $8.5 \mathrm{~g}$ and external measurements were as follows: total length, 101 $\mathrm{mm}$; length of tail, $40 \mathrm{~mm}$; length of hind foot, $7 \mathrm{~mm}$; length of ear, $14 \mathrm{~mm}$; length of forearm, $38 \mathrm{~mm}$. The testes measured $4 \times 2 \mathrm{~mm}$. Skull measurements were as follows: greatest length of skull, $14.2 \mathrm{~mm}$; breadth across canines, $4.9 \mathrm{~mm}$; interorbital breadth, $4.0 \mathrm{~mm}$; zygo- matic breadth, $9.9 \mathrm{~mm}$; cranial breadth, 7.2 $\mathrm{mm}$; length of maxillary toothrow, $5.4 \mathrm{~mm}$; and width across molars, $6.6 \mathrm{~mm}$. Dentition: i $1 / 3$, c $1 / 1$, p $1 / 2, \mathrm{~m} \mathrm{3/3}$, total 30 . The coloration of the individual was dark brown. The bat was kept as a voucher specimen and deposited in the Museum of Southwestern Biology (MSB:Mamm:291773), and tissues also were preserved (NK\# 257417).

\section{Discussion}

Our review of literature and museum records documented many records of $N$. humeralis beyond the former western and northern edges of its range and provides evidence for the species' continued westward expansion across the Great Plains (Fig. 1). Numerous sites within the newly expanded distribution yielded multiple captures of volant young and reproductive females (Dowler et al. 1999, Sparks and Choate 2000, Lane et al. 2003, Geluso et al. 2008, Serbousek and Geluso 2009, Johnson and Geluso 2017). We suspect that this species will continue to expand its distribution and increase in abundance throughout the Great Plains. Although expansion of wooded habitats is associated with the expansions of tree-roosting bats, abandoned settlements (e.g., old school houses, churches, and houses) might also have served as stepping stones for this species to expand into and across the Great Plains (Baker and Ward 1967, Chapman and Chapman 1990).

In light of recent distributional changes for some eastern bat species (Hall 1981, Benedict et al. 2000, Brant and Dowler 2000, Geluso et al. 2005, White et al. 2006, Armstrong et al. 
2006, Valdez et al. 2009, Riedle and Matlack 2013, Geluso and Geluso 2016, this study), it is important for researchers to be aware of the possibility of encountering eastern species inhabiting western portions of North America. Ruling out a species based purely on historical distributions might lead to improper identification in hand and via acoustic software. We encourage researchers to know the characteristics of $N$. humeralis and other eastern bat species and retain voucher materials (entire specimen or wing punch) to positively confirm species occurrences beyond distributional limits. Yates (1985) states that voucher specimens represent vital, nonrenewable resources that serve to physically and permanently document the occurrence and identity of a species. Thus, voucher specimens make historical comparison possible (Yates 1985). In addition, we recommend that individuals with questionable identifications should be kept as voucher specimens for later identification via genetic confirmation or examination of skull characteristics.

Technological advancements in recent years have led to surveys of bats via recording and discrimination of acoustical echolocation calls (e.g., Lemen et al. 2015, Russo and Voigt 2016). Reducing the possible number of species through regional libraries aids in proper identification of calls based on the species likely to be recorded in an area. However, ruling out some species based on distribution alone will likely lead to misidentification of echolocation call sequences. If acoustic equipment is used for surveys, we suggest that problematic calls should elicit netting surveys and that verification of species presence be limited to visual identification in hand.

Our capture of an evening bat in New Mexico represents the first individual reported in the state, as well as the farthest west occurrence of the species in North America (Fig. 1). The previous westernmost record in Presidio County, Texas, was $475 \mathrm{~km}$ east of our locality (Dowler et al. 1999). The route the New Mexico individual used to reach southwestern New Mexico is unclear. This specimen resembled the eastern subspecies on the basis of its dark coloration (Davis 1944), indicating that this individual more likely originated from the east rather than Mexico where the other subspecies occurs (Davis 1944). The capture of a male matches previous data showing that this sex typically remains in southern reaches of the range in summer (Jones 1967, Watkins 1969). Schmidly and Jones (2001) speculated that the Rio Grande has been a route for eastern bats to travel westward into previously unoccupied areas. The riparian corridor of the Rio Grande leads into southern New Mexico and, thus, it could have been used by this individual to reach the Mimbres River. Furthermore, records from western Texas might also indicate that the individual traversed eastern New Mexico to reach the Mimbres River. Other individuals could be residing in habitats along one of these 2 routes; thus, future research is warranted to determine the status of this species in New Mexico. This capture of a single individual in southwestern New Mexico is best referred to as an extralimital record and should be considered as such until more individuals are captured in the state. We suggest that more surveys should be conducted in eastern Colorado and eastern New Mexico to further corroborate our predictions and better define the current distributional limits of $N$. humeralis in North America. Such surveys also will provide important baseline information for future studies. Because species distributions are not static and continually change, understanding historical and current ranges is imperative with respect to future habitat and climate shifts (Parris and Hazell 2005, Kurta et al. 2007).

\section{ACKNOWLEDGMENTS}

We thank Kenneth N. Geluso for assistance in the field, Martha Cooper and Dave Gori for allowing us access to conduct biological surveys of mammals on lands owned by the Nature Conservancy in New Mexico, Ginny Seamster of the New Mexico Department of Game and Fish for technical matters associated with this research, and Jeremy White, Letitia Reichart, and 2 anonymous reviewers for comments on early versions of this manuscript. We would also like to thank those that provided information on museum specimens, including Lynda Louks (COU), Noman Horner and Ray Willis (MWSU), and Darren Pollock (ENMU). This project was funded, in part, by the Share with Wildlife program of the New Mexico Department of Game and Fish and State Wildlife Grant T-32-4 \#6 during the inventory of mammals on the Mimbres and Gila rivers in southwestern New Mexico. 


\section{Literature Cited}

Altringham, J.D. 2011. Roosting and feeding ecology. Pages 137-174 in Bats: from evolution to conservation. Oxford University Press, New York, NY.

Ammerman, L.K., C.L. Hice, and D.J. Schmidly. 2012. Bats of Texas. Texas A\&M University Press, College Station, TX.

Armstrong, D.M., R.A. Adams, and K.E. Taylor. 2006. New records of the eastern pipistrelle (Pipistrellus subflavus) in Colorado. Western North American Naturalist 66:268-269.

BAKER, R.J., AND C.M. WARD. 1967. Distribution of bats in southeastern Arkansas. Journal of Mammalogy 48: $130-132$.

BENEDICT, R.A. 2004. Reproductive activity and distribution of bats in Nebraska. Western North American Naturalist 64:231-248.

Benedict, R.A., P.W. Freeman, and H.H. Genoways. 1996. Prairie legacies-mammals. Pages 149-166 in F.B. Samson and F.L. Knopf, editors, Prairie conservation: preserving North America's most endangered ecosystem. Island Press, Washington, DC.

Benedict, R.A., H.H. Genoways, and P.W. Freeman. 2000. Shifting distributional patterns of mammals in Nebraska. Transactions of the Nebraska Academy of Sciences 26:55-84.

Boyles, J.G., AND L.W. RobBins. 2006. Characteristics of summer and winter roost trees used by evening bats (Nycticeius humeralis) in southwestern Missouri. American Midland Naturalist 155:210-220.

Brant, J.G., AND R.C. DowLER. 2000. Noteworthy record of the Seminole bat, Lasiurus seminolus (Chiroptera: Vespertilionidae), in Val Verde County Texas. Texas Journal of Science 52:353-355.

Chapman, S.S., AND B.R. Chapman. 1990. Bats from the coastal region of southern Texas. Texas Journal of Science 42:13-22.

ChoAte, J.R., AND K.M. REed. 1986. Historical biogeography of the woodchuck in Kansas. Prairie Naturalist 18:37-42.

Davis, W., AND D. Schmiduy. 1994. The mammals of Texas. Texas Parks and Wildlife Department, Austin, TX.

DAvis, W.B. 1944. Notes on Mexican mammals. Journal of Mammalogy 25:370-403.

Demere, K.D., A.M. Lewis, B. Mayes, R.J. BaKer, And L.K. Ammerman. 2012. Noteworthy records for 14 bat species based on specimens submitted to the Texas Department of State Health Services. Occasional Papers: Museum of Texas Tech University 315:1-12.

Dowler, R.C., R.C. Dawkins, and T.C. MaXwell. 1999. Range extensions for the evening bat (Nycticeius humeralis) in west Texas. Texas Journal of Science 51:193-195.

Dowler, R.C., T.C. Maxwell, and D.S. Marsh. 1992. Noteworthy records of bats from Texas. Texas Journal of Science 44:121-123.

Geluso, K. 2004. Westward expansion of the eastern fox squirrel (Sciurus niger) in northeastern New Mexico and southeastern Colorado. Southwestern Naturalist 49:111-116.

Geluso, K. 2006. Bats in a human-made forest of central Nebraska. Prairie Naturalist 38:13-23.

Geluso, K., J.P. Damm, and E.W. Valdez. 2008. Lateseasonal activity and diet of the evening bat (Nycti- ceius humeralis) in Nebraska. Western North American Naturalist 68:21-24.

Geluso, K., T.R. Mollhagen, J.M. Tigner, and M.A. BOGAN. 2005. Westward expansion of the eastern pipistrelle (Pipistrellus subflavus) in the United States, including new records from New Mexico, South Dakota, and Texas. Western North American Naturalist 65:405-409.

Geluso, K.N., AND K. Geluso. 2016. Bats of Kimball and Cheyenne counties, Nebraska. Pages 183-200 in R.W. Manning, J.R. Goetze, and F.D. Yancey II, editors, Contributions in natural history: a memorial volume in honor of Clyde Jones. Special Publications Number 65, Museum of Texas Tech University, Lubbock, TX.

HaLL, E.R. 1981. The mammals of North America. 2nd edition. John Wiley \& Sons, New York, NY.

Hall, E.R., AND K.R. Kelson. 1959. The mammals of North America. Ronald Press, New York, NY

Hunt, J.C. 1965. The forest that men made. American Forests 71:32-35, 48-50.

Johnson, O.J., AND K. Geluso. 2017. Distributional and reproductive records of bats from south-central Nebraska. Occasional Papers, Museum of Texas Tech University 347:1-15.

JoHnson, W.C. 1994. Woodland expansion in the Platte River, Nebraska: patterns and causes. Ecological Monographs 64:45-84.

JONES, D. 1967. Growth, development, and wing loading in the evening bat, Nycticeius humeralis (Rafinesque). Journal of Mammalogy 48:1-19.

Kurta, A.L., L. Winhold, J.O. Whitaker JR., and R. Foster. 2007. Range expansion and changing abundance of the eastern pipistrelle (Chiroptera: Vespertilionidae) in the central Great Lakes region. American Midland Naturalist 157:404-411.

Lane, J.E., C.L. Buck, And R.M. Brigham. 2003. The bat fauna of southeastern South Dakota. Prairie Naturalist 35:246-256.

Lemen, C.L., P.W. Freeman, J.A. White, and B.R. AnderSEN. 2015. The problem of low agreement among automated identification programs for acoustical surveys of bats. Western North American Naturalist $75: 218-225$.

Manning, R.W., J.K. Jones JR., R.R. Hollander, and C. Jones. 1987. Notes on distribution and natural history of some bats on the Edwards Plateau and in adjacent areas of Texas. Texas Journal of Science 39:279-285.

Mather, E.C. 1972. The American Great Plains. Annals of the Association of American Geographers 62: $237-257$.

Parris, K.M., and D.L. Hazell. 2005. Biotic effects of climate change in urban environments: the case of the grey-headed flying-fox (Pteropus poliocephalus) in Melbourne, Australia. Biological Conservation 124:267-276.

Phelps, K.L., C.J. Schmidt, and J.R. Chonte. 2008. Presence of the evening bat (Nycticeius humeralis) in westernmost Kansas. Transactions of the Kansas Academy of Science 111:159-160.

Riedle, T.D.H., and R.S. MatLack. 2013. Bats of Palo Duro Canyon State Park, Texas: community composition, abundance, and seasonal activity. Western North American Naturalist 73:89-97.

Russo, D., AND C.C. VoIGT. 2016. The use of automated identification of bat echolocation calls in acoustic 
monitoring: a cautionary note for a sound analysis. Ecological Indicators 66:598-602.

Scheel, D., T.L.S. Vincent, and G.N. Cameron. 1996. Global warming and the species richness of bats in Texas. Conservation Biology 10:452-464.

SCHMIDLY, D.J., AND C. JoNEs. 2001. 20th century changes in mammals and mammalian habitats along the Rio Grande/Rio Bravo from Fort Quitman to Amistad. Pages 177-204 in Binational Symposium Rio Grande/ Rio Bravo: Ft. Quitman to Amistad Reservoir. Proceeding, 14 June 2000, Ciudad Juarez, Chihuahua, Mexico. U.S. Department of the Interior. Secretariat of Environmental and Natural Resources, International Boundary and Water Commission, Washington, DC.

Serbousek, M.R., and K. Geluso. 2009. Bats along the Republican River and its tributaries in southwestern Nebraska: distribution, abundance and reproduction. Western North American Naturalist 69:180-185.

Sikes, R.S., W.L. Gannon, and Animal Care and Use Committee of the American Society of MamMALOGISTS. 2011. Guidelines of the American Society of Mammalogists for the use of wild mammals in research. Journal of Mammalogy 92:235-253.

SPARKS, D.W., AND J.R. ChOATE. 2000. Distribution, natural history, and conservation status, and biogeography of bats in Kansas. Pages 173-228 in J.R. Choate, editor, Reflections of a naturalist: papers honoring Professor Eugene D. Fleharty. Fort Hays Studies, Special Issue 1, Hays, KS.

SwIER, V.J. 2006. Recent distribution and life history information for bats of eastern South Dakota. Occasional Papers, Museum of Texas Tech University 264:1-21.

Valdez, E.W., K. Geluso, J. Foote, G. Allison-Kosior, AND D.M. Roemer. 2009. Spring and winter records of the eastern pipistrelle (Perimyotis subflavus) in southeastern New Mexico. Western North American Naturalist 69:396-398.

WATKINS, L.C. 1969. Observations on the distribution and natural history of the evening bat (Nycticeius humeralis) in northwestern Missouri and adjacent Iowa. Transactions of the Kansas Academy of Sciences 72:330-336.

Watkins, L.C. 1972. Nycticeius humeralis. Mammalian Species 23:1-4.

WatKIns, L.C., AND K.A. Shump JR. 1981. Behavior of the evening bat Nycticeius humeralis at a nursery roost. American Midland Naturalist 105:258-268.

White, J.A., P.R. Moosman Jr., C.H. Kilgore, and T.L. BEST. 2006. First record of the eastern pipistrelle (Pipistrellus subflavus) from southern New Mexico. Southwestern Naturalist 51:420-422.

Wilkins, K.T., W.J. Boeer, D.S. Rogers, and W.S. Modi. 1979. Records for eight Texas mammals. Florida Scientist 42:59-60.

Wilson, G.M., AND J.R. ChOATE. 1996. Continued westward dispersal of the woodchuck in Kansas. Prairie Naturalist 28:21-22.

Yancey, F.D., II, AND C. Jones. 2006. Changes in distributions of bats in Texas. Occasional Papers: Museum of Texas Tech University 258:1-5.

YATES, T.L. 1985. The role of voucher specimens in mammal collections: characterization and funding responsibilities. Acta Zoologica Fennica 170:81-82.

Received 12 September 2016 Accepted 17 April 2017 Published online 19 July 2017 